\title{
Molecular and morphological differentiation between the crop and weedy types in velvetleaf (Abutilon theophrasti Medik.) using a chloroplast DNA marker: seed source of the present invasive velvetleaf in Japan
}

\author{
S Kurokawa ${ }^{1}, \mathrm{H}_{\text {Shibaike }}{ }^{2}, \mathrm{H}$ Akiyama $^{2}$ and Y Yoshimura ${ }^{1}$ \\ ${ }^{1}$ National Institute of Livestock and Grassland Science, National Agricultural Research Organization, Tochigi 329-2793, Japan; \\ ${ }^{2}$ National Institute for Agro-environmental Sciences, Ibaraki 305-8604, Japan
}

\begin{abstract}
A comparison of chloroplast DNA (cpDNA) sequences was carried out between the crop and weed types of Abutilon theophrasti to clarify the seed source of the present weedy velvetleaf in Japan. A sequencing analysis of approx. $6 \%$ of the chloroplast genome (ca $10 \mathrm{kbp}$ ) detected three nucleotide substitutions, one six-base-pair insertion/deletion (indel) and one 30-base pair inversion, which distinguish two haplotypes of cpDNA. A PCR-based survey of the indel and the inversion revealed that the 93 accessions of velvetleaf collected from the world could be divided into two groups. A morphological marker (capsule color) could be used to discriminate the crop type and the weed type, and hence, along with cpDNA haplotype, to distinguish three genotypes
\end{abstract}

(Type I, II, and III). All Japanese cultivars and crop accessions from other countries were Type I. Weed types were divided into Type II and III. All of the samples from the USA, and the samples taken from grain imports to Japan were Type III. Since most of the weedy types distributed in Japan were of Type III, it is argued that they were introduced as seeds in the imported grain. We also found that the Type II plants sporadically occurred in Japan. It is suggested that they originated as hybrids, with indigenous cultivars as the maternal ancestor. Such hybrids must have survived since the cessation of velvetleaf cultivation about a century ago. Heredity (2004) 93, 603-609. doi:10.1038/sj.hdy.6800569 Published online 8 September 2004

Keywords: velvetleaf; chloroplast DNA; seed flow; exotic weed; imported grains

\section{Introduction}

Velvetleaf (Abutilon theophrasti Medik.) has been cultivated as a fiber crop in China, England, and the United States (Spencer, 1984). Especially, in China, which is thought to be the origin of velvetleaf, usage may date back to 2000 BC or earlier (Spencer, 1984). In Japan, this plant is thought to have been introduced as a fiber crop from China in ancient times and was cultivated all over Japan until about 100 years ago (Fukane, 918; Yoshikawa, 1919). Velvetleaf was not recognized as a weed until the 1980s (Ito, 1993). In the mid-1980s, however, this plant suddenly became one of the most troublesome exotic weeds of forage crop field all over Japan (Nishida and Shimizu, 1999). Questionnaires were mailed in 1993 to research stations and/or extension stations in each prefecture, to collect data concerning exotic weed distribution, abundance, and crop losses in arable land (Nishida and Shimizu, 1999). The survey revealed that velvetleaf was the most abundant and widespread exotic weed species. A correlation was found between velvet-

Correspondence: S Kurokawa, National Institute of Livestock and Grassland Science, National Agricultural Research Organization, 768 Senbonmatsu, Nishinasuno, Nasu, Tochigi 329-2793, Japan.

E-mail:shunji@affrc.go.jp

Received 1 May 2003; accepted 30 June 2004; published online 8 September 2004 leaf abundance and crop losses, and in $20 \%$ of the places where velvetleaf occurred 'big' or 'very big' on crop losses were recorded, revealing velvetleaf as the most troublesome weed (Nishida and Shimizu, 1999).

There are two possible reasons for the outbreak of velvetleaf in Japanese forage crop fields: (1) the accidental release of a cultivar and (2) an invasion of a new strain from abroad.

Shimizu et al (1996) found some velvetleaf seeds in the imported sorghum and soybean from the United States and lupine from Australia consistent with the second scenario. In a previous study, we found that there are two different growth habits in velvetleaf, that is, crop and weed types (Kurokawa et al, 2003a). The contaminants detected in imported grain showed strong weedy growth, and were genetically different from the crop type indigenous to Japan (Kurokawa et al, 2003a, b). We also found that ivory capsule color could be used as a morphological genetic marker to discriminate the crop type from the weed type. The ivory phenotype is governed by recessive gene (s) (Kurokawa et al, 2003a).

The aim of the present study is to clarify the origin of the present invasive velvetleaf of Japan based on the seed flow using chloroplast DNA markers. Uniparentally inherited organelle markers can be used to estimate the relative gene flow by pollen $v$ s seed by comparison with biparentally inherited nuclear markers such as the 
allozymes (Petit et al, 1993; Ennos, 1994). In angiosperms, chloroplast genes are only dispersed in seeds; therefore, cpDNA markers can be used to follow seed movement. Since the samples used in this study were collected from all over the world, it is possible to classify the samples based on their genetic profiles, and to compare the profiles to assess the origin of the recent outbreak.

\section{Materials and methods}

\section{Plant materials}

A total of 93 samples were used in this study (Table 1), from five sample groups: (1) quarantine samples: five accessions contaminating grain imported from the United States and Australia sampled at the port of Kashima in 1994; (2) US samples: 12 accessions sampled at a corn belt in the United States in 1999 from where many of the quarantine samples originated; (3) Japanese samples:
24 accessions sampled around Honshu Island in Japan in 1998 representing the present velvetleaf outbreak; (4) Japanese crop cultivars: 11 Japanese cultivars from germplasm of the Genebank kindly provided by the National Institute of Agrobiological Sciences, Tsukuba, Ibaraki 305-8602, Japan; and (5) USDA samples: 41 accessions from USDA Germplasm worldwide collection kindly provided by the United States Department of Agriculture (USDA), ARS, SRPIS, Griffin, GA 30223-1797, USA. The USDA samples were made by NI Vaviov Institute of Plant Industry, whose accessions are thought to have been collected between 1916 and 1940 (Loskutov, 1999).

\section{DNA extraction}

Total DNA was extracted using a DNeasy Plant Mini kit (QIAGEN), or by a modified method by Liu et al (1995). DNA extraction by a DNeasy Plant Mini kit was performed following the protocol supplied by the

Table 1 Summary of samples used in this study

\begin{tabular}{|c|c|c|c|c|c|c|}
\hline Sample group & Origin & Locality & Habitat or source & Collected year & Weed or cropa & $\begin{array}{l}\text { Number of } \\
\text { accessions }\end{array}$ \\
\hline Quarantine sample & $\begin{array}{l}\text { Australia } \\
\text { United States }\end{array}$ & Kashima port & Imported grains & 1994 & Weed & $\begin{array}{l}1 \\
4\end{array}$ \\
\hline \multirow[t]{4}{*}{ US sample } & \multirow[t]{4}{*}{ United States } & Indiana State & $\begin{array}{l}\text { Corn field, soybean field } \\
\text { and open space }\end{array}$ & 1999 & Weed & 5 \\
\hline & & Illinois State & Corn field & 1999 & Weed & 2 \\
\hline & & Missouri State & Corn field & 1999 & Weed & 2 \\
\hline & & Nebraska & $\begin{array}{l}\text { Corn field, grain sorghum } \\
\text { field }\end{array}$ & 1999 & Weed & 3 \\
\hline Japanese sample & Japan & Honshu island & $\begin{array}{l}\text { Corn field, waste land, } \\
\text { meadow and open space }\end{array}$ & 1997 & Weed & 24 \\
\hline Japanese cultivar & Japan (cultivar) & & Japan Genebank & Unknown & Crop & 11 \\
\hline \multirow[t]{25}{*}{ USDA sample } & Africa & & USDA Germplasm & Unknown & Crop & 1 \\
\hline & China & & USDA Germplasm & Unknown & Crop & 6 \\
\hline & Denmark & & USDA Germplasm & Unknown & Weed & 1 \\
\hline & Ethiopia & & USDA Germplasm & Unknown & Crop & 2 \\
\hline & Former soviet union & & USDA Germplasm & Unknown & Crop & 1 \\
\hline & France & & USDA Germplasm & Unknown & $\begin{array}{l}\text { Weed } \\
\text { Crop }\end{array}$ & $\begin{array}{l}1 \\
1\end{array}$ \\
\hline & Germany & & USDA Germplasm & Unknown & Weed & 1 \\
\hline & \multirow[t]{2}{*}{ India } & & USDA Germplasm & Unknown & Weed & 2 \\
\hline & & & & & Crop & 1 \\
\hline & \multirow[t]{2}{*}{ Italy } & & USDA Germplasm & Unknown & Weed & 2 \\
\hline & & & & & Crop & 1 \\
\hline & Japan & & USDA Germplasm & Unknown & Crop & 3 \\
\hline & Kazahstan & & USDA Germplasm & Unknown & Weed & 1 \\
\hline & Middle Asia & & USDA Germplasm & Unknown & Crop & 1 \\
\hline & \multirow[t]{2}{*}{ Russian Federation } & & USDA Germplasm & Unknown & Crop & 1 \\
\hline & & & & & Weed & 3 \\
\hline & Netherlands & & USDA Germplasm & Unknown & Weed & 1 \\
\hline & Poland & & USDA Germplasm & Unknown & Weed & 1 \\
\hline & Portugal & & USDA Germplasm & Unknown & $\begin{array}{l}\text { Weed } \\
?\end{array}$ & $\begin{array}{l}1 \\
1\end{array}$ \\
\hline & Romania & & USDA Germplasm & Unknown & Weed & 1 \\
\hline & Sweden & & USDA Germplasm & Unknown & Weed & 1 \\
\hline & Switzerland & & USDA Germplasm & Unknown & Weed & 1 \\
\hline & Ukraine & & USDA Germplasm & Unknown & Weed & 2 \\
\hline & United Kingdom & & USDA Germplasm & Unknown & Weed & 1 \\
\hline & United States & & USDA Germplasm & Unknown & $?$ & 1 \\
\hline Total & & & & & & 93 \\
\hline
\end{tabular}

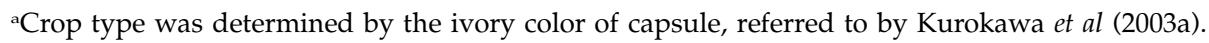


manufacturer. The modified method of Liu et al (1995) was performed as below. One individual plant was used as material from each accession. Approximately $100 \mathrm{mg}$ of leaves stored frozen in a $1.5 \mathrm{ml}$ tube were ground in the same tube in the presence of $100 \mu \mathrm{l}$ of isolation buffer (0.3 M NaCl, $50 \mathrm{mM}$ Tris- $\mathrm{HCl}$ pH 7.5, 20 mM EDTA, $0.5 \%$ SDS, $5 \mathrm{M}$ urea and $5 \%$ phenol) using a microtube homogenizer (S-203, Ikeda Sci., Tokyo, Japan) at about 200-300 rpm. Another $400 \mu \mathrm{l}$ of isolation buffer and $400 \mu \mathrm{l}$ of phenol/choloform/isoamyl alcohol (25:24:1) were added to the tube, mixed, and centrifuged at $15000 \mathrm{rpm}$ for $5 \mathrm{~min}$ in a microcentrifuge. DNA was recovered by ethanol precipitation and dissolved in a $50 \mu \mathrm{l} \mathrm{TE}$ buffer containing RNase $(20 \mu \mathrm{g} / \mathrm{ml})$, and then stored at $-20^{\circ} \mathrm{C}$.

\section{DNA amplification}

Approximately $10 \mathrm{ng}$ of total DNA was used in the amplification reaction. A total of 19 universal primer pairs proposed by various authors (Hiratsuka et al, 1989; Taberlet et al, 1991; Liston, 1992; Demesure et al, 1995; Petit et al, 1998) were used to amplify partial regions of chloroplast DNA. The thermal cycling was performed in a GeneAmp 9700 (Applied Biosystems) or GeneAmp 2400 (Perkin Elmer).

PCR products amplified were purified by MicroSpin S300 HR Columns (Amersham Biosciences KK) before sequencing. Direct sequencing was performed with universal primers by an ALFexpress DNA sequencer (Amersham Pharmacia Biotech) or ABI 373 DNA sequencer (Applied Biosystems). Consequently, sequences of approximately $10 \mathrm{kbp}$ of chloroplast DNA were determined.

\section{Results}

\section{Nucleotide polymorphisms in chloroplast DNA of} velvetleaf

Preliminarily, a comparison of the chloroplast DNA sequences was carried out using eight universal primer sets on accessions PI499240, PI499255, and 94-62-L as representatives of crop and weedy growth habits of velvetleaf (cf. Tables 4 and 5). As a result, three nucleotide substitutions, one six-base-pair indel and one 30-basepair inversion, were detected among three samples in three regions of cpDNA genome, generated by three primer sets (trnL-trnF: GGTTCAAGTCCCTCTATCCC and ATTTGAACTGGTGACACGAG; trnH-trnK: ACG GGAATTGAACCCGCGCA and CCGACTAGTTCCGGG TTCGA; and trnT-psbC: GCCCTTTTAACTCAGTG GTA and GAGCTTGAGAAGCTTCTGGT). Aligning the nucleotide polymorphisms detected among the three samples, it was found that there were two cpDNA haplotypes in velvetleaf, that is, haplotype A and B. To screen the 93 accessions of velvetleaf as to the cpDNA haplotypes, we developed two PCR-based markers to detect the size differentiation of the six-base-pair indel and the direction of 30-base-pair inversion (Table 2, Figure 1). To detect the six-base-pair indel, the PCR products were separated on $6 \%$ acryl amide gel in a Trisborate-EDTA buffer containing $6 \mathrm{M}$ urea, and detected with a Cy5 florescence labeled primer using an ALFexpress DNA sequencer with a fragment analyser 1.02 (Amersham Pharmacia Biotech). For the 30-base-pairs
Table 2 Size differences between haplotype A and B on two cpDNA markers

\begin{tabular}{lcc}
\hline Haplotype & $\begin{array}{c}\text { Fragment sizes by } \\
\text { six-base-pair ins/del } \\
\text { marker }(b p)\end{array}$ & $\begin{array}{c}\text { Fragment sizes by } \\
\text { 30-base-pair inversion } \\
\text { marker }(b p)\end{array}$ \\
\hline A & 457 & ca 600 \\
B & 463 & ca 1200 \\
\hline
\end{tabular}
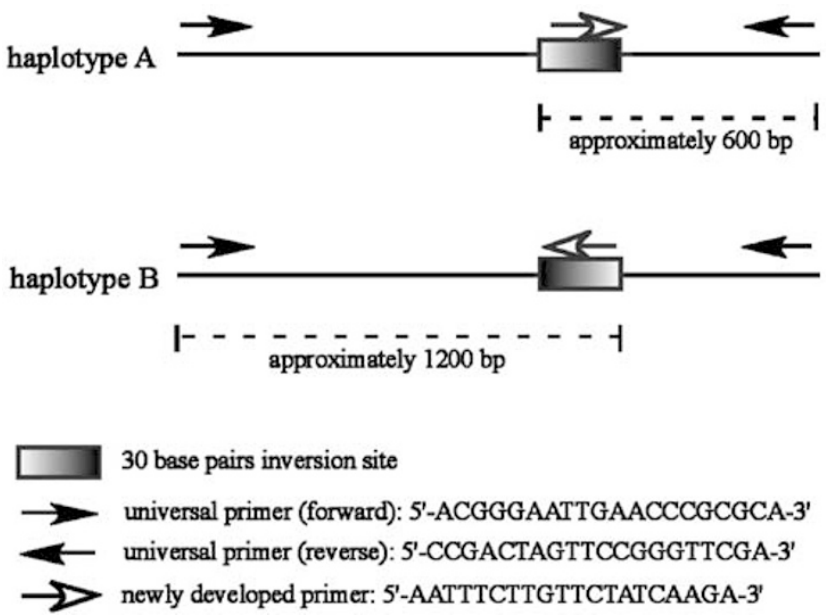

Figure 1 Discrimination of chloroplast haplotypes of velvetleaf by polymerase chain reaction using two universal primers and another newly developed primer to the inverted site in the $\operatorname{trn} \mathrm{H}$ (GUG) and trnK (UUU) 3'exon region.

inversion, we designed another primer located in the inverted site, and inferred the direction of inverted sequence by the sized of PCR products amplified. Initial denaturation was for $5 \mathrm{~min}$ at $94^{\circ} \mathrm{C}$, which was followed by 30 cycles of $30 \mathrm{~s}$ at $94^{\circ} \mathrm{C}, 30 \mathrm{~s}$ at $47^{\circ} \mathrm{C}, 1 \mathrm{~min}$ at $72^{\circ} \mathrm{C}$, and a final $7 \mathrm{~min}$ extension at $72^{\circ} \mathrm{C}$ in a GeneAmp 9700 (Applied Biosystems). The PCR products were separated on $1 \%$ agarose gel in a Tris-acetate-EDTA buffer, stained with ethidium bromide, and visualized under UV light. The primer was designed using an OLIGO Primer Analysis Software for Windows ver. 6 (Molecular Biology Insights, Inc.). As a result, these accessions were successfully classified into two haplotypes (Tables 4 and 5).

Discrimination of three genotypes for 93 accessions of velvetleaf using genetic markers

Previously, we had found two capsule color variants governed by nuclear gene(s) (Kurokawa et al, 2003a). Ebony (dominant) and ivory (recessive) were traits that discriminated the weed and crop types, respectively. In combination with the cpDNA haplotype, we could classify all accessions to three genotypes: Type I, II and III (Table 3). Type I have an ivory capsule with a cpDNA haplotype A, while Type II and III have an ebony capsule with cpDNA haplotype A and B, respectively.

Genotypes of 93 accessions of velvetleaf are summarized in Tables 4 and 5. All Japanese crop cultivars and of USDA crop samples were Type I. The USDA weed 
samples comprised Type II and Type III. All the quarantine samples from grain imports and the US samples were Type III. Most of the Japanese samples were also Type III, although some accessions from Nagano and Tochigi were Type II (accession numbers k00004, k00008, k00139, and k00205).

\section{Discussion}

Source of the present velvetleaf in Japan

Previously, we had found that there are two different growth habits in velvetleaf and that they also show

Table 3 Discrimination of velvetleaf of three genotypes by cpDNA and capsule color variations

\begin{tabular}{llc}
\hline$c p D N A$ haplotype & Capsule color & Genotype \\
\hline A & Ivory & I \\
A & Ebony & II \\
B & Ebony & III \\
\hline
\end{tabular}

differences in morphology and ISSR variation (Kurokawa et al, 2003a,b). The contaminants detected in imported grain were found to be a potential origin of the present invasive velvetleaf in Japan, because they show weedy growth habit and are genetically distinct. The present study showed that all accessions could be divided into three genotypes (Type I, II, and III) by combination of the cpDNA haplotype and capsule color variation. All Japanese crop cultivars and crops from other countries were Type I (Tables 4 and 5). On the other hand, the quarantine samples contaminating grain imported from abroad and the US samples (the main origin of the quarantine samples) were Type III (Table 5). These results suggest that Type III, which has a different cpDNA haplotype from Japanese cultivars, has been entering Japan via imported grain from the United States of America and Australia, since most of the Japanese weed samples were also Type III. The findings suggest that the cause of the recent outbreak of invasive velvetleaf in Japan is that foreign weedy strains have entered Japan, contaminating major imported grain,

Table 4 Genotype of USDA germplasm accessions based on cpDNA and capsule color

\begin{tabular}{|c|c|c|c|c|c|}
\hline Continent & Country & Accession & CpDNA haplotype & Capsule color & Genotype \\
\hline \multirow[t]{3}{*}{ Africa } & Africa & PI499215 & A & Ivory & I \\
\hline & Ethiopia & PI499208 & A & Ivory & I \\
\hline & & PI499252 & A & Ivory & I \\
\hline \multirow[t]{13}{*}{ Asia } & China & PI499211 & A & Ivory & I \\
\hline & & PI499216 & A & Ivory & I \\
\hline & & PI499217 & A & Ivory & I \\
\hline & & PI499218 & A & Ivory & I \\
\hline & & PI499229 & A & Ivory & I \\
\hline & & PI499248 & A & Ivory & I \\
\hline & India & PI499223 & B & Ebony & III \\
\hline & & PI499235 & B & Ebony & III \\
\hline & & PI499250 & A & Ivory & I \\
\hline & Japan & PI499210 & A & Ivory & I \\
\hline & & PI499213 & A & Ivory & I \\
\hline & & PI499255ª & A & Ivory & I \\
\hline & Middle Asia & PI499243 & A & Ivory & I \\
\hline America & United States & PI499254 & A & Ivory & I \\
\hline \multirow[t]{24}{*}{ Europe } & Denmark & PI499237 & A & Ebony & II \\
\hline & Former Soviet Union & PI499253 & A & Ivory & I \\
\hline & France & PI499233 & A & Ebony & II \\
\hline & & PI499245 & A & Ivory & I \\
\hline & Germany & PI499220 & B & Ebony & III \\
\hline & Italy & PI499212 & A & Ebony & II \\
\hline & & PI499234 & A & Ivory & I \\
\hline & & PI499246 & A & Ivory & I \\
\hline & Kazahstan & PI499209 & B & Ebony & III \\
\hline & Netherlands & PI499239 & A & Ebony & II \\
\hline & Poland & PI499249 & A & Ebony & II \\
\hline & Portugal & PI499222 & B & Ebony & III \\
\hline & & PI499236 & B & Ebony & III \\
\hline & Romania & PI499224 & B & Ebony & III \\
\hline & Russian Federation & PI499214 & A & Ivory & I \\
\hline & & PI499219 & B & Ebony & III \\
\hline & & PI499227 & A & ? & I or II \\
\hline & & PI499240a & A & Ebony & II \\
\hline & & PI499242 & B & Ebony & III \\
\hline & Sweden & PI499232 & A & Ebony & II \\
\hline & Switzerland & PI499225 & B & Ebony & III \\
\hline & Ukraine & PI499238 & B & Ebony & III \\
\hline & & PI499241 & B & Ebony & III \\
\hline & United Kingdom & PI499226 & A & Ebony & II \\
\hline
\end{tabular}

${ }^{a}$ Accessions used for the preliminary experiment to detect sequence polymorphisms. 
Table 5 Genotype of velvetleaf accessions in the quarantine sample, the US sample and the Japanese sample

\begin{tabular}{|c|c|c|c|c|c|c|c|c|}
\hline Category & Continent & Country & Locality & Habitat & Accession & cpDNA haplotype & Capsule color & $\overline{\text { Genotype }}$ \\
\hline \multirow{5}{*}{ Quarantine sample } & America & United States & Kashima port & & $94-1-S$ & B & Ebony & III \\
\hline & & & & & $94-22-\mathrm{H}$ & B & Ebony & III \\
\hline & & & & & $94-62-\mathrm{L}^{\mathrm{a}}$ & B & Ebony & III \\
\hline & & & & & $94-67-\mathrm{P}$ & $\mathrm{B}$ & Ebony & III \\
\hline & Australia & Australia & Kashima port & & $94-20-V$ & B & Ebony & III \\
\hline \multirow[t]{12}{*}{ US sample } & America & United States & Ilinois & Corn field & k00239 & B & Ebony & III \\
\hline & & & & & k00240 & B & Ebony & III \\
\hline & & & Indiana & Corn field & k00235 & B & Ebony & III \\
\hline & & & & & k00237 & B & Ebony & III \\
\hline & & & & & k00238 & B & Ebony & III \\
\hline & & & & Open space & k00234 & B & Ebony & III \\
\hline & & & & Soybean field & k00236 & B & Ebony & III \\
\hline & & & Missouri & Corn field & k00241 & B & Ebony & III \\
\hline & & & & & k00242 & B & Ebony & III \\
\hline & & & Nebraska & Corn field & k00243 & B & Ebony & III \\
\hline & & & & & k00245 & B & Ebony & III \\
\hline & & & & Grain sorghum field & k00244 & $\mathrm{B}$ & Ebony & III \\
\hline \multirow[t]{24}{*}{ Japanese sample } & Asia & Japan & Gunma & Corn field & k00013 & B & Ebony & III \\
\hline & & & Hiroshima & Corn field & k00011 & B & Ebony & III \\
\hline & & & Miyagi & Corn field & k00003 & B & Ebony & III \\
\hline & & & Nagano & Corn field & k00004 & A & Ebony & $\mathrm{II}^{\mathrm{b}}$ \\
\hline & & & & & k00005 & B & Ebony & III \\
\hline & & & & & k00006 & B & Ebony & III \\
\hline & & & & & k00007 & B & Ebony & III \\
\hline & & & & & k00008 & $\mathrm{A}$ & Ebony & $\mathrm{II}^{\mathrm{b}}$ \\
\hline & & & Nara & Corn field & k00002 & B & Ebony & III \\
\hline & & & & Waste field & k00012 & B & Ebony & III \\
\hline & & & Niigata & Meadow & k00015 & B & Ebony & III \\
\hline & & & & Grassland & k00020 & B & Ebony & III \\
\hline & & & Okayama & Corn field & k00009 & B & Ebony & III \\
\hline & & & & & k00010 & B & Ebony & III \\
\hline & & & Tochigi & Corn field & k00022 & B & Ebony & III \\
\hline & & & & & k00049 & B & Ebony & III \\
\hline & & & & & k00079 & B & Ebony & III \\
\hline & & & & & k00109 & B & Ebony & III \\
\hline & & & & & k00139 & A & Ebony & $\mathrm{II}^{\mathrm{b}}$ \\
\hline & & & & & k00148 & B & Ebony & III \\
\hline & & & & & k00178 & B & Ebony & III \\
\hline & & & & & k00205 & A & Ebony & $\mathrm{II}^{\mathrm{b}}$ \\
\hline & & & Tokyo & Open space & k00016 & B & Ebony & III \\
\hline & & & Yamagata & Corn field & k00001 & $\mathrm{B}$ & Ebony & III \\
\hline \multirow{11}{*}{ Japanese cultivar } & Asia & Japan & & & JP25777 & A & Ivory & I \\
\hline & & & & & JP25778 & $\mathrm{A}$ & Ivory & I \\
\hline & & & & & JP25779 & A & Ivory & $\mathrm{I}$ \\
\hline & & & & & JP25780 & A & Ivory & I \\
\hline & & & & & JP25781 & A & Ivory & $\mathrm{I}$ \\
\hline & & & & & JP25782 & A & Ivory & I \\
\hline & & & & & JP25783 & A & Ivory & I \\
\hline & & & & & JP25784 & A & Ivory & I \\
\hline & & & & & JP25785 & A & Ivory & I \\
\hline & & & & & JP25786 & A & Ivory & I \\
\hline & & & & & JP25787 & A & Ivory & I \\
\hline
\end{tabular}

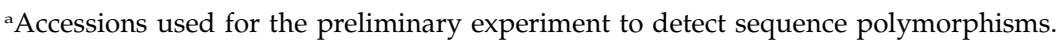

${ }^{b}$ Accessions classified as Type II found in Japanese sample.

which amount to 30 million tons per year (FAOSTAT, 2003).

The small number of Type II plants might result from crosses between the Type I (maternal) and Type III (paternal) plants during the period when velvetleaf cultivar (Type I) was still cultivated in Japan (Table 5), which have subsequently survived despite the cessation of the cultivation of velvetleaf. If this is true, other factors in addition to immigration could have contributed to the outbreak, including changes in weeding methods.
Gene flow between the crop and weed types of velvetleaf Gene flow can be expected to occur in many crop/weed complexes if the crop and the weed have sympatric ranges, are sexually compatible, have flowering times that overlap, and share a common pollinator (Arriola and Ellstrand, 1997). In fact, spontaneous gene flow between crop and weed has been reported in several cases (eg, Helianthus, Arias and Rieseberg, 1994; Sorghum, Arriola and Ellstrand, 1996; Raphanus, Klinger et al, 1991, 1992; Brassica, Jorgensen and Andersen, 1994; Oryza, Langevin 
et al, 1990; Setaria, Till-Bottraud et al, 1992; Cucurbita, Kirkpatrick and Wilson, 1988; Wilson et al, 1994).

In velvetleaf, Kurokawa et al (2003a) revealed that the crop and weed types are sexually compatible and that their flowering times are overlapping. Therefore, most of the above conditions for gene flow are thought to have been satisfied, if the weed type occurred in Japan when velvetleaf was cultivated as fiber crop. At present, we find that Type II has the ebony capsules specific to the weed type, but a cpDNA of haplotype A, the same as the crop type (Table 5). It is suggested that the gene flow from the weed type (Type III) into the crop type (Type I) has occurred. Theoretically, the converse could also have occurred, that is, gene flow from the crop type into the weed type (Type IV, as it were). Unfortunately, our classification by the capsule color and the chloroplast variation could not distinguish the Type IV because the capsule color is a dominant marker. Either hybrid, Type II and IV, might have a different adaptive ability to Japanese field conditions from their ancestors, as found in the other species (eg Oryza, Langevin et al, 1990; Raphanus, Klinger and Ellstrand, 1994; Brassica, Linder and Schmitt, 1995). Further study will be needed to elucidate the differences between types that explain the invasion of velvetleaf in Japan.

\section{Acknowledgements}

We thank Dr K Ishikawa and Dr O Watanabe for their help in sampling in the US. Special thanks to $\mathrm{Mr} \mathrm{H}$ Iizuka, Mr S Shimizu, Ms T Nishida, Dr H Morita, Ms T Onoue for providing valuable seeds. We are grateful for the valuable suggestion of Dr M Ide and Dr K Ito as well. Seeds with PI numbers shown in Table 1 were kindly provided by the United States Department of Agriculture (USDA), the Agricultural Research Service (ARS), Southern Regional PI Station (SRPIS), Griffin, GA 30223-1797, USA. Seeds of 11 Japanese crop varieties from germplasm of the Genebank were kindly provided by the National Institute of Agrobiological Sciences, Tsukuba, Ibaraki 305-8602, Japan. We thank to editors and two anonymous reviewers for valuable comments and suggestions.

\section{References}

Arias DM, Rieseberg LH (1994). Gene flow between cultivated and wild sunflowers. Theor Appl Genet 89: 655-660.

Arriola PE, Ellstrand NC (1996). Crop-to-weed gene flow in the genus Sorghum (Poaceae): spontaneous interspecific hybridization between johnsongrass, Sorghum halpense, and crop sorghum, S. bicolor. Am J Bot 83: 1153-1160.

Arriola PE, Ellstrand NC (1997). Fitness of interspecific hybrids in the genus Sorghum: persistence of crop genes in wild populations. Ecol Appl 7: 512-518.

Demesure B, Sodzi N, Petit RJ (1995). A set of universal primers for amplification of polymorphic non-coding regions of mitochondrial and chloroplast DNA in plants. Mol Ecol 4: 129-131.

Ennos RA (1994). Estimating the relative rates of pollen and seed migration among plant populations. Heredity $\mathbf{7 2}$ 250-259.

FAOSTAT (2003). FAO Statistical Databases http:/ /apps.fao.org
Fukane S (918). (compiled) Honzo-Wamyo, revised by Taki, G in 1796, re-compiled by Yosano $\mathrm{H}$, Masamune A, Yosano A in 1926. Nippon-Koten-Zenshu-Kankou-kai, Tokyo.

Hiratsuka J, Shimada H, Whittier R, Ishibashi T, Sakamoto M, Mori $\mathrm{M}$ et al (1989). The complete sequence of the rice Oryza sativa chloroplast genome intermolecular recombination between distinct transfer RNA genes accounts for a major plastid DNA inversion during the evolution of the cereals. Mol Gen Genet 217: 185-194.

Ito M (1993). Zasso-Gaku-Souron, Yoken-do: Toyko. pp 26.

Jorgensen RB, Andersen B (1994). Spontaneous hybridization between oilseed rape (Brassica napus) and weedy B.campestris (Brassicaceae): a risk of growing genetically modified oilseed rape. Am J Bot 81: 1620-1626.

Kirkpatrick KJ, Wilson HD (1988). Interspecific gene flow in Cucurbita: C. Texana vs C. Pepo. Am J Bot 75: 519-527.

Klinger T, Arriola PE, Ellstrand NC (1992). Crop-weed hybridization in radish (Raphanus sativus): effects of distance and population size. Am J Bot 79: 1431-1435.

Klinger T, Elam DR, Ellstrand NC (1991). Radish as a model system for the study of engineered gene escape rates via crop-weed mating. Conserv Biol 5: 531-535.

Klinger T, Ellstrand NC (1994). Engineered genes in wild populations: fitness of weed-crop hybrids of Raphanus sativus. Ecol Appl 4: 117-120.

Kurokawa S, Shimizu N, Uozumi S, Yoshimura Y (2003a). Intraspecific variation in morphological characteristics and growth habit of newly and accidentally introduced velvetleaf (Abutilon theophrasti Medik.) into Japan. Weed Biol Manage 3: 28-36.

Kurokawa S, Shimizu N, Uozumi S, Yoshimura Y (2003b). ISSR variation in a worldwide collection of velvetleaf (Abutilon theophrasti) and the genetic background of weedy strains mingled in grains imported into Japan. Weed Biol Manage 3: 179-183.

Langevin SA, Clay K, Grace JB (1990). The incidence and effects of hybridization between cultivated rice and its related weed red rice (Oryza sativa L.). Evol Int J Org Evol 44: 1000-1008.

Linder R, Schmitt J (1995). Potential persistence of escaped transgenes: performance of transgenic oil-modified Brassica seeds and seedlings. Ecol Appl 5: 1056-1068.

Liston A (1992). Variation in the chloroplast genes rpoC1 and rpoC2 of the genus Astragalus (Fabaceae): evidence from restriction site mapping of a PCR-amplified fragment. Am J Bot 79: 953-961.

Liu Y-G, Mitsukawa N, Oosumi T, Whittier RF (1995). Efficient isolation and mapping of Arabidopsis thaliana T-DNA insert junctions by thermal asymmetric interlaced PCR. Plant $J \mathbf{8}$ : 457-463.

Loskutov IG (1999). Vavilov's collecting missions and expeditions (1922-1940) The Far East. In Vavilov and his Institute. A History of the World Collection of Plant Genetic Resources in Russia, International Plant Genetic Resources Institute: Rome. pp 69-73.

Nishida T, Shimizu N (1999). Alien plant invasion into forage crop fields and artificial pastures in Japan. In: Yano E, Matsuo K, Shiyomi M, Andow DA (eds) Biological Invasions of Ecosystem by Pests and Beneficial Organisms, National Institute of Agro-Environmental Science: Tsukuba. pp 128-142.

Petit RJ, Demesure B, Dumolin S (1998). cpDNA and mtDNA primers in plants. In: Karp A, Isaac PG, Ingram DS (eds) Molecular Tools for Screening Biodiversity, Chapman \& Hall: London. pp 256-261.

Petit RJ, Kremer A, Wagner DB (1993). Finite island model for organelle and nuclear genes in plants. Heredity $\mathbf{7 1}$ : 630-641.

Shimizu N, Enomoto T, Kurokawa S (1996). Identification of alien weeds contaminated with feed material cereals imported. I. Species and its background. Weed Res Japan 41(Suppl): 212-213. 
Spencer NR (1984). Velvetleaf, Abutilon theophrasti (Malvaceae), history and economic impact in the United States. Econ Bot 38: 407-416.

Taberlet P, Gielly L, Pautou G, Bouvet J (1991). Universal primers for amplification of three non-coding regions of chloroplast DNA. Plant Mol Biol 17: 1105-1109.

Till-Bottraud I, Reboud X, Brabant P, Lefranc M, Rherissi B, Vedel F et al (1992). Outcrossing and hybridization in wild and cultivated foxtail millet consequences for the release of transgenic crops. Theor Appl Genet 83: 940-946.

Wilson HD, Lira R, Rodriguez I (1994). Crop/weed gene flow: Cucurbita argyrosperma Huber and C. fraterna L. H. Bailey (Cucurbitaceae). Econ Bot 48: 293-300.

Yoshikawa Y (1919). Bauma. In: Kougei-Sakumotsu-Kakuron Vol 1 Seni-Sakumotsu, Sankyo Press: Tokyo. pp 143-145. 